
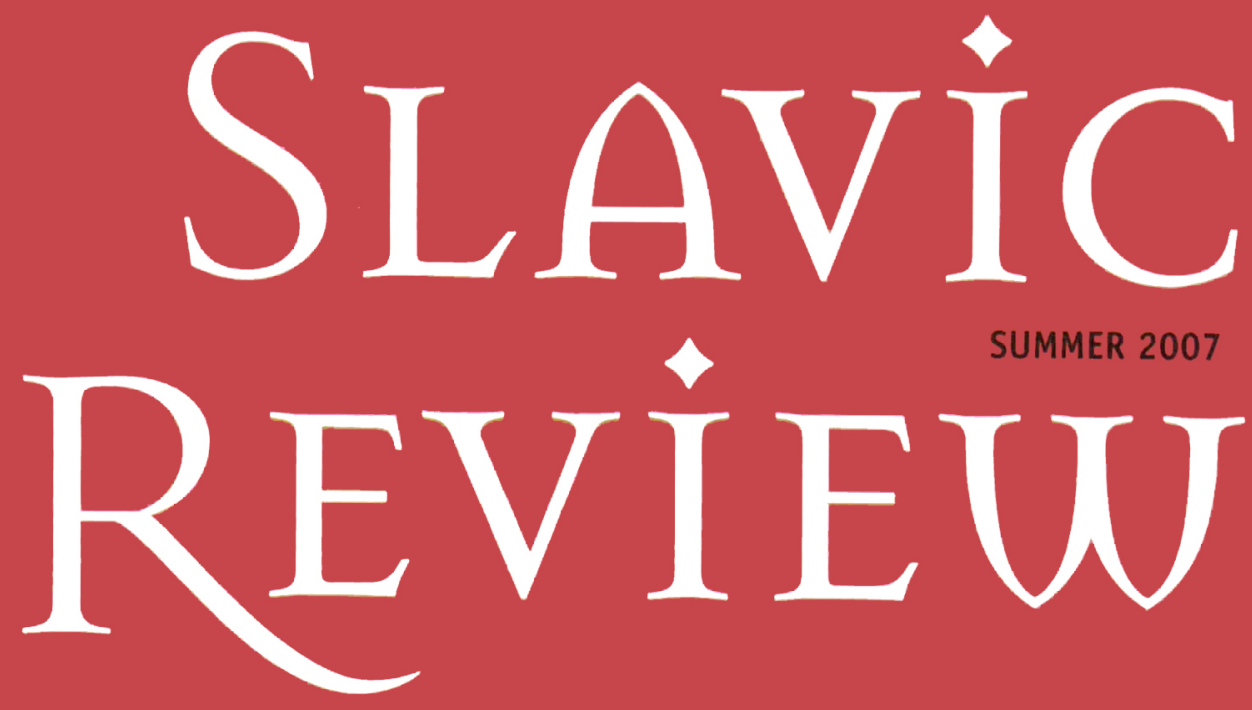

Interdisciplinary Quarterly of Russian, Eurasian, and East European Studies

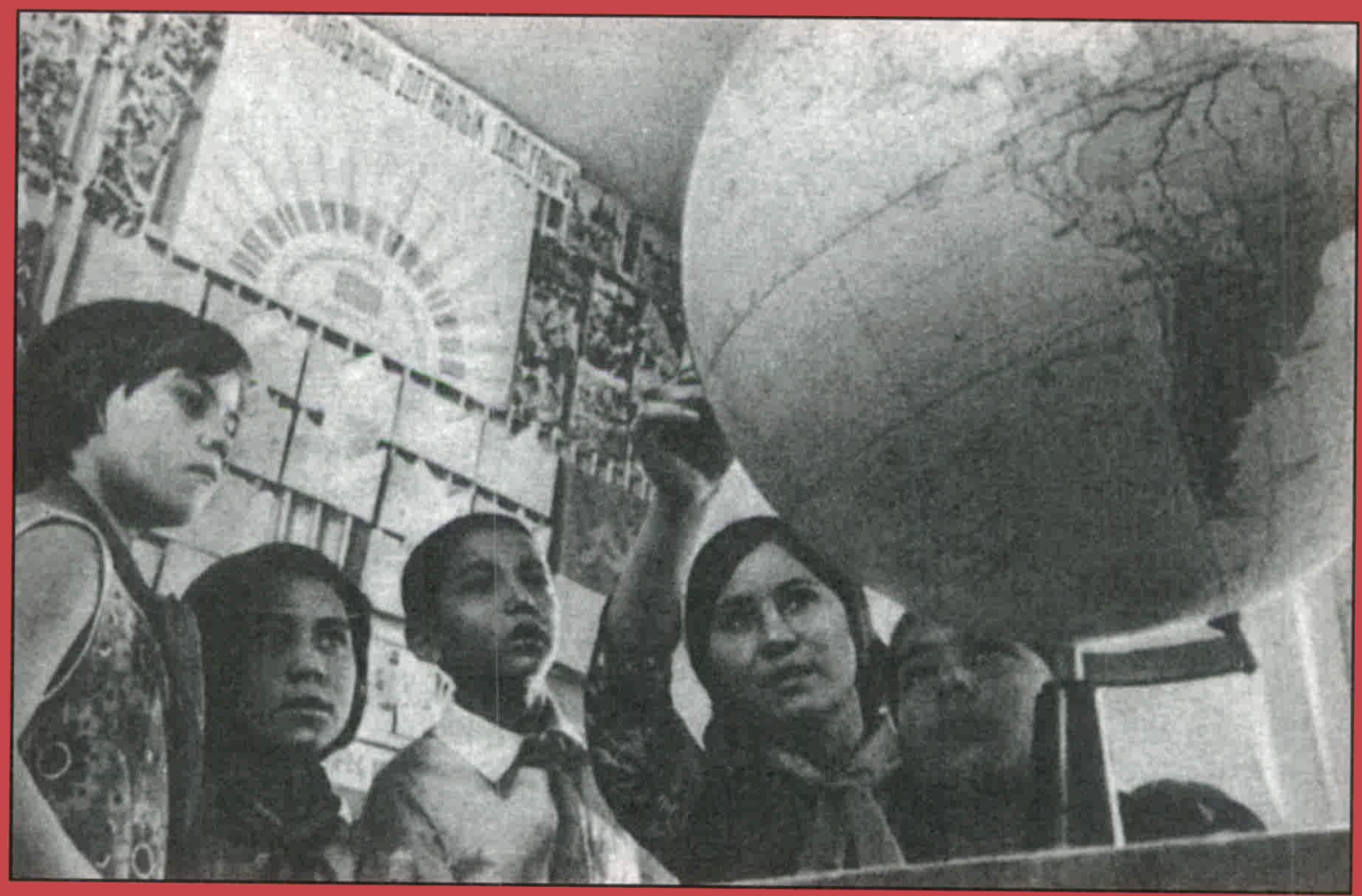




\title{
EDITOR
}

\author{
MARK D. STEINBERG \\ MANAGING EDITOR, JANE T. HEDGES \\ EDITORIAL ASSISTANTS \\ Randall S. Dills Tatiana Kuzmič Zsuzsânna Magdó
}

EDITORIAL BOARD

\begin{abstract}
History
John Connelly, University of California, Berkeley • Yaroslav Hrytsak, L'viv National University and Central European University, Budapest - Adeeb Khalid, Carleton College - William Rosenberg, University of Michigan - Maria Todorova, University of Illinois • Stefan Troebst, University of Leipzig • Lynne Viola, University of Toronto • Mark von Hagen, Columbia University • Sergei Zhuravlev, Institute of Russian History of the Russian Academy of Sciences, Moscow
\end{abstract}

\section{Literature and the Arts}

Clare Cavanagh, Northwestern University - Gregory Freidin, Stanford University • Catriona Kelly, Oxford University - Christina Kiaer, Northwestern University • Judith Kornblatt, University of Wisconsin, Madison - Michał Paweł Markowski, Jagellonian University, Kraków • Eric Naiman, University of California, Berkeley • Catharine Nepomnyashchy, Columbia Unizersity • Andrei Zorin, Oxford University

\section{Social Sciences}

Judit Bodnár, Central European University, Budapest $\bullet$ M. Steven Fish, University of California, Berkeley - Susan Gal, University of Chicago • Elena Gapova, European Humanities University, Vilnius-Minsk • Grigorii Golosov, European University, St. Petersburg • Bruce Grant, New York University • Jan Kubik, Rutgers University • Pauline Luong, Brown University • Blair Ruble, Kennan Institute

Cover image from A. E. Izmailov, Izuchenie razvitiia kul'tury narodov Srednei Azii i Kazakhstana v kurse istorii v 8-10 klassakh (Moscow, 1986), 199.

The editors assume no responsibility for statements of fact or opinion made by contributors.

Slavic Review (formerly The American Slavic and East European Review) is published quarterly by the American Association for the Advancement of Slavic Studies, Inc., and is sent to all association members. Members also receive NewsNet, the AAASS newsletter. Membership is open to individuals interested in Slavic studies and the study of the non-Slavic peoples of eastern Europe and Eurasia. Applications for membership are accepted by the AAASS, 8 Story Street, Cambridge, MA 02138; (617) 495-0677.

Membership Dues: students or those with salaries under $\$ 20,000-\$ 35.00$; those with salaries $\$ 20,000-\$ 29,999-\$ 50.00 ; \$ 30,000-\$ 39,999-\$ 65.00 ; \$ 40,000-\$ 49,999-\$ 80.00 ; \$ 50,000-$ $\$ 59,999-\$ 100.00 ; \quad \$ 60,000-\$ 69,999-\$ 115.00 ; \quad \$ 70,000-\$ 99,999-\$ 135.00 ; \quad \$ 100,000-$ $\$ 124,999-\$ 160.00 ; \$ 125,000$ and over $-\$ 180.00$. Joint members with one subscription to Slavic Review, add $\$ 35.00$ to dues of higher paid member. Subscriptions without membership are $\$ 150.00$ within the United States, $\$ 170.00$ in Canada and Mexico, and $\$ 190.00$ overseas. For members or subscribers living in Canada or Mexico, please add $\$ 20.00$ for shipping; for members or subscribers living overseas, please add $\$ 35.00$. Single current issues and back issues to subscribers are $\$ 25.00$; for members, $\$ 20.00$ each. Correspondence regarding membership, subscriptions, changes of address, or items for NewsNet should be sent to the AAASS headquarters at Cambridge.

Copyright $\odot 2007$ Slavic Review ISSN 0037-6779 by the American Association for the Advancement of Slavic Studies, Inc. Permission to reprint must generally be obtained from Slavic Review. Copying is permitted in accordance with the fair use guidelines of the US Copyright act of 1976. The association permits the following additional educational uses without permission or payment of fees: academic libraries may place materials from Slavic Review on reserve (in multiple photocopied or electronically retrievable form) for students enrolled in specific courses; teach- 


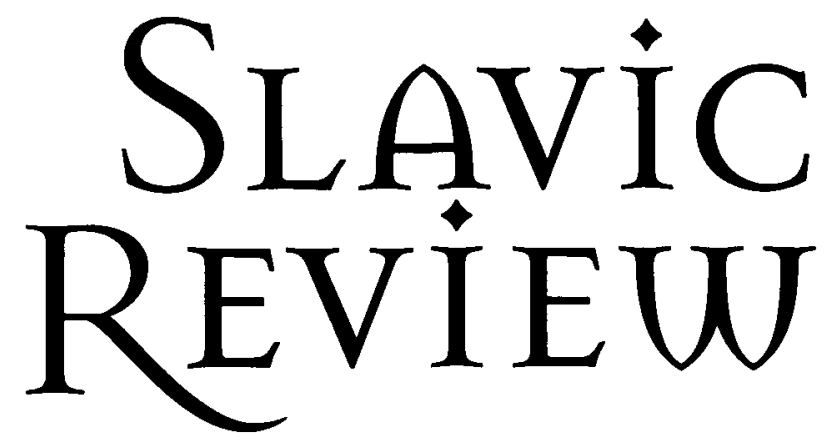

INTERDISCIPLINARY QUARTERLY OF RUSSIAN, EURASIAN, AND EAST EUROPEAN STUDIES

VOLUME 66 NUMBER 2 • SUMMER 2007

CONTRIBUTORS

vi

ABSTRACTS

vii

\section{ARTICLES}

Derzhavin's Metaphysics of Morality

189

AARON BEAVER

Dostoevskii's Geography: Centers, Peripheries, and Networks in Demons

ANNE LOUNSBERY

Unruly Felons and Civilizing Wives: Cultivating Marriage

in the Siberian Exile System, 1822-1860

ABBY M. SCHRADER

Story, Time, and Dependent Nationhood in the Uzbek History

Curriculum

SHOSHANA KELLER

Finding a Home for Television in the USSR, 1950-1970

KRISTIN ROTH-EY

\section{BOOK REVIEWS}

Andrew Baruch Wachtel, Remaining Relevant after Communism:

The Role of the Writer in Eastern Europe (Eliot Borenstein)

Lowell W. Barrington, ed., After Independence: Making and

Protecting the Nation in Postcolonial and Postcommunist States

(Andrew C. Janos) 
Philip G. Roeder and Donald Rothchild, eds., Sustainable Peace: Power and Democracy after Civil Wars (Barnett R. Rubin)

Joshua A. Tucker, Regional Economic Voting: Russia, Poland, Hungary, Slovakia, and the Czech Republic, 1990-1999 (Terry D. Clark)

Adam Czarnota, Martin Krygier, and Wojciech Sadurski, eds., Rethinking the Rule of Law after Communism (Kathryn Hendley)

Michael Neubert, ed., Virtual Slavica: Digital Libraries, Digital Archives (Michael Brewer)

Eric J. Goldberg, Struggle for Empire: Kingship and Conflict under Louis the German, 817-876 (Florin Curta)

Adrian O. Mandzy, A City on Europe's Steppe Frontier: An Urban History of Early Modern Kamianets-Podilsky, Origins to 1672 (Robert I. Frost)

Ela Bauer, Between Poles and Jews: The Development of Nahum Sokolow's Political Thought (Samuel D. Kassow)

Melissa Feinberg, Elusive Equality: Gender, Citizenship, and the Limits of Democracy in Czechoslovakia, 1918-1950 (Bradley F. Abrams)

Bradley F. Abrams, The Struggle for the Soul of the Nation: Czech Culture and the Rise of Communism (Mark Cornwall)

Miklós Lojkó, Meddling in Middle Europe: Britain and the "Lands Between," 1919-1925 (Peter Pastor)

Caroline Finkel, Osman's Dream: The Story of the Ottoman Empire, 1300-1923 (Karen Barkey)

Knut Andreas Grimstad and Ursula Phillips, eds., Gender and Sexuality in Ethical Context: Ten Essays on Polish Prose (Beth Holmgren)

Ewa Mazierska and Elżbieta Ostrowska, Women in Polish Cinema, with a supplementary chapter by Joanna Szwajcowska (Annette Insdorf)

János Kornai and Susan Rose-Ackerman, eds., Building a Trustworthy State in Post-Socialist Transition (Mitchell Orenstein)

Chris Hasselmann, Policy Reform and the Development of Democracy in Eastern Europe (Paul G. Lewis)

Tim Haughton, Constraints and Opportunities of Leadership in Post-Communist Europe (Silvia Miháliková)

John O'Brennan, The Eastern Enlargement of the European Union (James Sperling) 
Andrew A. Michta, The Limits of Alliance: The United States, NATO, and the EU in North and Central Europe (Laure Paquette)

John Rodden, Textbook Reds: Schoolbooks, Ideology, and Eastern German Identity (Alan Nothnagle)

Insa Theesfeld, A Common Pool Resource in Transition: Determinants of Institutional Change for Bulgaria's Postsocialist Irrigation Sector (Mieke Meurs)

Stefan Rohdewald, "Vom Polocker Venedig": Kollektives Handeln sozialer Gruppen einer Stadt zwischen Ost- und Mitteleuropa (Mittelalter, frühe Neuzeit, 19. Jh. bis 1914) (Robert Blobaum)

Toomas Hiio, Meelis Maripuu, and Indrek Paavle, eds., Estonia 1940-1945: Reports of the Estonian International Commission for the Investigation of Crimes against Humanity (Andres Kasekamp)

Wendy Lower, Nazi Empire-Building and the Holocaust in Ukraine (William W. Hagen)

Guenter Lewy, The Armenian Massacres in Ottoman Turkey: A Disputed Genocide (Justin McCarthy)

Zina J. Gimpelevich, Vasil Bykaŭ: His Life and Works (Katharine Hodgson)

Laada Bilaniuk, Contested Tongues: Language Politics and Cultural Correction in Ukraine (Myroslav Shkandrij)

Eric A. Miller, To Balance or Not to Balance: Alignment Theory and the Commonwealth of Independent States (Andrei Tsygankov)

Bruno Coppieters and Robert Legvold, eds., Statehood and Security: Georgia after the Rose Revolution (Pavel K. Baev)

Farian Sabahi and Daniel Warner, eds., The OSCE and the Multiple Challenges of Transition: The Caucasus and Central Asia (Anoush Ehteshami)

Dittmar Dahlmann, ed., Hundert Jahre Osteuropäische Geschichte: Vergangenheit, Gegenwart, und Zukunft (Philip Pajakowski)

Michael D. Gordin, A Well-Ordered Thing: Dmitrii Mendeleev and the Shadow of the Periodic Table (Mark B. Adams)

A. A. Komzolova, Politika samoderzhaviia v Severo-Zapadnom krae v epokhu Velikikh reform (Stephen M. Woodburn)

William C. Fuller Jr., The Foe Within: Fantasies of Treason and the End of Imperial Russia (Eric Lohr)

O. V. Budnitskii, O. V. Belova, V. E. Kelner, and V. V. Mochalova, eds., Mirovoi krizis 1914-1920 godov $i$ sud'ba vostochnoevropeiskogo evreistva (Aaron J. Cohen) 
Corinna Kuhr-Korolev, "Gezähmte Helden": Die Formierung der Sowjetjugend 1917-1932 (Michaela Pohl)

Kate Transchel, Under the Influence: Working-Class Drinking, Temperance, and Cultural Revolution in Russia, 1895-1932 (Stephen White)

Matthias Heeke, Reisen zu den Sowjets: Der ausländische Tourismus im Rußand 1921-1941. Mit einem bio-bibliographischen Anhang zu 96 deutschen Reiseautoren (Erika Wolf)

Norman E. Saul, Friends or Foes? The United States and Russia, 1921-1941 (Paul Dukes)

Hans-Michael Miedlig, Am Rande der Gesellschaft im Frühstalinismus: Die Verfolgung der Personen ohne Wahlrecht in den Städten des Moskauer Gebiets 1928-1934 (Kees Boterbloem)

Arja Rosenholm and Sari Autio-Sarasmo, eds., Understanding Russian Nature: Representations, Values, Concepts (Nicholas B. Breyfogle)

Daniel Rancour-Laferriere, Traditsiia pochitaniia ikon Bogomateri $v$ Rossii glazami amerikanskogo psikhoanalitika / The Joy of All Who Sorrow: Icons of the Mother of God in Russia, trans. A. G. Georgiev (Robert Bird)

Helena Goscilo and Andrea Lanoux, eds., Gender and National Identity in Twentieth-Century Russian Culture (Dan Healey)

Christina Kiaer and Eric Naiman, eds., Everyday Life in Early Soviet Russia: Taking the Revolution Inside (Anne E. Gorsuch)

Kevin M. F. Platt and David Brandenberger, eds., Epic Revisionism: Russian History and Literature as Stalinist Propaganda (David L. Hoffmann)

Alessandra Tosi, Waiting for Pushkin: Russian Fiction in the Reign of Alexander I (1801-1825) (Paul Austin)

Thomas Seifrid, The Word Made Self: Russian Writings on Language, 1860-1930 (Edna Andrews)

Anna Lisa Crone and Jennifer Jean Day, My Petersburg/Myself: Mental Architecture and Imaginative Space in Modern Russian Letters (Julie Buckler)

Kirsten Blythe Painter, Flint on a Bright Stone: A Revolution of Precision and Restraint in American, Russian, and German Modernism (Justin Doherty)

Gerard de Vries and D. Barton Johnson, Nabokov and the Art of Painting, with an essay by Liana Ashenden (Priscilla Meyer) 366

Maria Gough, The Artist as Producer: Russian Constructivism in Revolution (Patricia Railing) 
Christina Kiaer, Imagine No Possessions: The Socialist Objects of Russian Constructivism (Jim Aulich)

Emma Widdis, Alexander Medvedkin (Denise J. Youngblood)

Lyubov Bugaeva and Eva Hausbacher, eds., Ent-Grenzen: Intellectuelle Emigration in der russischen Kultur des 20. Jahrhunderts / Za predelami: Intellektual'naia emigratsiia $v$ russkoi kul'ture $X X$ veka (Zina Gimpelevich)

Helen Kopnina, East to West Migration: Russian Migrants in Western Europe (Éva V. Huseby-Darvas)

Margaret Paxson, Solovyovo: The Story of Memory in a Russian Village (Caroline Humphrey)

Galina Lindquist, Conjuring Hope: Magic and Healing in Contemporary Russia (Margaret Paxson)

Anastasia V. Mitrofanova, The Politicization of Russian Orthodoxy: Actors and Ideas (Dimitry V. Pospielovsky)

Aleksandr Verkhovskii and Galina Kozhevnikova, eds., Etnicheskaia i religioznaia intolerantnost' v rossiiskikh SMI: Rezul'taty monitoringa 2001-2004 gg. (John F. Young)

Henry E. Hale, Why Not Parties in Russia? Democracy, Federalism, and the State (Andrew Konitzer)

Andrew Barnes, Owning Russia: The Struggle over Factories, Farms, and Power (Stephen Crowley)

Andrei Shleifer, A Normal Country: Russia after Communism (Pekka Sutela)

Stephen L. Webber and Jennifer G. Mathers, eds., Military and Society in Post-Soviet Russia (Kimberly Marten) 